\title{
Toward a New Metrics for the Evaluation of the Social Added Value of Social Enterprises
}

\section{Andrea Bassi and Giorgia Vincenti}

"The thing that count in life are not things"

(Anonymous)

"Not everything that counts can be counted, and not everything that can be counted counts"

(Albert Einstein)

\section{ABSTRACT}

There is a widespread dissatisfaction among nonprofit leaders and managers, private funders and public decision-makers concerning the current systems of social impact assessment of nonprofit organizations/social enterprises (NPO/SE).

The systems of performance measurement of NPO/SE vary greatly in relationship to a series of endogenous and exogenous variables related to different organizational environments: economic, political, social and cultural.

The aim of this article is to present an innovative theoretical framework on the basis of which it is possible to define a set of indicators for the evaluation of the social added value produced by NPO/SE.

Our hypothesis is that NPO/SE are characterized by their ability to generate different outcome at each of the dimensions of social life: micro, meso and macro. Meaning, a sense of responsibility at the micro level; relational goods at the meso level; and social capital at the macro level.

The article illustrates the assessment tool called S.A.V.E. applied, as empirical reference, to three Italian social enterprises operating in the field of health and social services (local welfare systems).

KEYWORDS: Social Impact Assessment, Social Added Value, Evaluation, Social Cooperatives.

ECONLIT DESCRIPTORS: M140, P130, Q130.

Reference: BASSI, A.\& VINCENTI, G. (2015): "Toward a New Metrics for the Evaluation of the Social Added Value of Social Enterprises", CIRIEC-España, Revista de Economía Pública, Social y Cooperativa, 83, 9-42.

Correspondence: Andrea Bassi and Giorgia Vincenti, Università di Bologna, andrea.bassi7@ unibo.it. 


\section{Hacia un nuevo sistema de medición para la evaluación del valor añadido social de las empresas sociales}

RESUMEN: Existe una insatisfacción generalizada entre los líderes y gestores de las entidades sin ánimo de lucro, los financiadores privados y los decisores públicos con respecto a los sistemas actuales de evaluación del impacto social de las organizaciones no lucrativas y empresas sociales (ONL/ES).

Los sistemas para medir el rendimiento (performance) de las ONL/ES varían mucho con respecto a una serie de variables endógenas y exógenas relacionadas con distintos entornos organizacionales: económicos, políticos, sociales y culturales.

El objetivo de este artículo es presentar un marco teórico innovador que sirva de base para poder definir un conjunto de indicadores para la evaluación del valor añadido social que producen las ONL/ES.

Nuestro hipótesis es que las ONL/ES se caracterizan por su capacidad de generar un resultado distinto en cada una de las dimensiones de la vida social: micro, meso y macro. Es decir: sentido de la responsabilidad a nivel micro, bienes relacionales a nivel meso y capital social a nivel macro.

El artículo ilustra la herramienta de evaluación denominada S.A.V.E., aplicada, como referencia empírica, a tres empresas sociales italianas que trabajan en el campo de los servicios socio-sanitarios (sistemas de bienestar locales).

PALABRAS CLAVE: Evaluación del impacto social, valor añadido social, cooperativas sociales.

\section{Vers de nouvelles mesures d'évaluation de la valeur ajoutée sociale des entreprises sociales}

RÉSUMÉ : Il existe une insatisfaction généralisée parmi les administrateurs et les directeurs d'organismes à but non lucratif, les investisseurs privés et les décideurs publics concernant les systèmes actuels d'évaluation de l'impact social des organismes à but non lucratif/entreprises sociales (OBNL/ES).

Les systèmes de mesure des performances des OBNL/ES varient grandement, selon une série de variables endogènes et exogènes liées à différents environnements organisationnels : économique, politique, social et culturel.

L'objectif de cet article est de présenter un cadre théorique innovant à partir duquel il serait possible de définir un ensemble d'indicateurs pour l'évaluation de la valeur ajoutée sociale produite par les OBNL/ES.

Nous partons de l'hypothèse selon laquelle les OBNL/ES sont caractérisées par leur capacité à générer différents résultats dans chacune des dimensions de la vie sociale, c'est-à-dire micro, méso et macro. Plus exactement, le sens des responsabilités au niveau microéconomique, les biens relationnels au niveau mésoéconomique et le capital social au niveau macroéconomique.

L'article présente l'outil d'évaluation appelé S.A.V.E. utilisé, comme référence empirique, pour trois entreprises sociales italiennes travaillant dans le secteur de la santé et des services sociaux (systèmes d'aide sociale locaux).

MOTS CLÉ : Évaluation de l'impact social, valeur ajoutée sociale, évaluation, coopératives sociales. 


\section{1.- Introduction 1}

There is a widespread dissatisfaction among nonprofit leaders and managers, private funders and public decision-makers concerning the current systems of social impact assessment of nonprofit organizations/social enterprises (NPO/SE).

The systems of performance measurement of NPO/SE vary greatly in relationship to a series of endogenous and exogenous variables related to different organizational environments: economic, political, social and cultural.

The aim of this article is to present an innovative theoretical framework on the basis of which it is possible to define a set of indicators for the evaluation of the social added value produced by NPO/SE.

Our hypothesis is that NPO/SE are characterized by their ability to generate different outcome at each of the dimensions of social life: micro, meso and macro. Meaning, a sense of responsibility at the micro level; relational goods at the meso level; and social capital at the macro level.

The article illustrates the assessment tool called S.A.V.E. applied, as empirical reference, to three Italian social enterprises operating in the field of health and social services (local welfare systems).

The first paragraph deals with the issue of social impact. Taking into account of the fact that there is an increasing and converging interest among policy makers, scholars and researchers, and third sector practitioners concerning the social added value nonprofit organizations and social enterprises create in the society as a whole. We argue that there are many factors inducing this pressure on NPO / SE towards the adoption of assessment systems for the evaluation of the (social) impact produced by their activities and programs; among them a key-role is played by the economic and financial crisis started in October 2008, and the consequent shrinkage of financial resources both for institutional donors (grant-making foundations) and public administration.

In the second paragraph we illustrate the logic and the internal dimensions of the theoretical framework we called S.A.V.E. - meaning social added value evaluation model - trying to emphasize it strengths in comparison to other tools of nonprofit performance assessment. 
The third paragraph is dedicated to present a short history of the evolution of the social cooperative movement in Italy and the research design of the exploratory empirical inquiry we carried on.

The fourth paragraph illustrates the characteristics of the three social cooperatives analyzed, and it presents the outcomes of the case studies we conducted.

Finally, the conclusive section summarizes the main results illustrated in the article and opens new hypothesis for further research projects.

\section{2.- Social Impact Assessment: Whether, Why, What, Who, When, How?}

There is an increasing pressure toward NPO / SE for the adoption of assessment systems for the evaluation of the (social) impact produced (induced) by their activities, programs, projects, etc. Where does this pressure came from? And why now?

In our opinion there are, at least, three main reason explaining these trends.

\subsection{Converging trends}

First of all there is a wide change in the attitude of the citizens as consumers towards the role and function of private for profit enterprises in society. This change in life styles, opinions and attitudes put pressure on firms influencing their corporate behavior, pushing them to adopt a more social responsible orientation towards the environment and its stakeholders.

The corporations are asked nowadays to fulfill the requirements of a "triple bottom line": the monetary rewards of the shareholders (economic feasibility); the improvement in quality of life of several stakeholders: workers, clients/users, suppliers, people living in the local community where the enterprise is located (social sustainability); the preservation of the natural environment (responsibility towards the new generations).

This trends goes in the direction of the necessity for the corporations to act in a more transparent way (publicness social accountability) and be able to demonstrate their impacts (positive or negative) in the territories where they are located. 
Secondly in the last two decades there has been a deep process of reform in the Public Administration, involving the top managerial levels, due to the adoption of the principles of the so called "New Public Management".

This new managerial style stresses the public administration officials to embrace "market" or "business-like" techniques in the planning, implementation, delivering and evaluation of services and provisions, such as: cost-benefits analysis, goal-achievement, project-planning, direct personal responsibility, system of incentives (rewards) and penalties.

This trend put a pressure on the public managers to demonstrate the results of their actions (efficiency and effectiveness) and of the work of the offices they are leading. Since in many fields of activities (welfare, health, education) the public bodies operate through (by means of) third sector - nonprofit suppliers, this new managerial philosophy implies a growing (increasing) request these organizations to show the (social) impact of their programs and services delivered under contract with the public administration (value for money).

In parallel in many western countries the systems of welfare provisions undertake a deep and wide reform process (Hemerijck 2012; Pierson 2011) inspired by the so called "personalization" principle, aimed to give to the citizen (the final beneficiary of services provision) more "power of choice" and "voice" (empowerment).

This reform implied a radical change in the way public bodies sustain and finance the delivering of social, health and education services by third parties. This change has been defined as the movement from "supply-side" to "demand-side" model of financing the provision of services (Standing, 2004).

The new model of financing implies the implementation of an "accreditation procedure" through which the suppliers should be recognized by a specialized Agency (public body) to be qualified (licensed) to deliver a specific typology of services (or a set of services).

The public administration (usually the municipality) than set up a procedure for the citizens in order to be qualified as "having the right" to receive a particular type of service. Those citizens included in this condition than receive a certain amount of "purchase power" in form of vouchers or in form of money (personal budget). The vouchers and the personal budget than can be "spent" in order to buy services from the "licensed" delivering organizations, in the so called "regulated social market".

It is easy to see as this new model of financing put the deliverers in competition among them in order to attract (to catch) the former users of welfare provisions, now "clients" in the social market. The competition stresses the capacity and the ability of the social services deliverers to demonstrate the effectiveness of their operational structure, in respect to the other possible competitors (both for profit and nonprofit). 
This constitutes another very powerful incentive toward the adoption of systems of social impact assessment among the NPO / SE working the welfare field.

Thirdly there is a wide movement inside the so called Third Sector (meaning organizations that are not private for profit (business) neither part of the public administration structure) toward the "marketization" or "commercialization" of their activities and the "professionalization" of their human resources (both paid staff and volunteers).

The first phenomenon "marketization" indicate the growing tendency of NPO / SE to sell their goods and services directly to the clients (Brennan, Cass, Himmelweit, Szebehely 2012; Meagher and Szebehely 2013). The income structure of NPO / SE is undergoing (undertaking) a deep change showing an increasing quota of revenues coming from direct selling and a corresponding decrease of those originated from "donations" and contracts with the public administration.

This new differentiation of the portfolio of the NPO / SE entails the outbreak of new forms of organization which present characteristic of the three principal typologies: firms (for profit sector), bureau (public sector) and associations (nonprofit / third sector). Some authors have called this phenomena "hybridization" and the result of the organizational process "hybrid organizations" (Billis, 2010).

Also this trend goes in the direction of pushing the capacity of the new (social) enterprises (Defourny, Hulgard, Pestoff, 2014) to demonstrate the (social) impact of their activities comparing to the "traditional" nonprofit organizations based mainly on donatives income.

The second aspect, professionalization, is concerning the trend toward a progressive substitution of volunteers with paid staff in the key positions of NPO/SE, which take place in the last two decade of the previous century. This tendency related to the hiring of high skilled and high educated personnel in the mid and top management positions in the nonprofit sector, is due by both the development of Master degrees in "nonprofit management" and "social entrepreneurship leadership" in many Universities (especially in Business Schools); and the increasing complexity of the accreditation process and the requirements imposed by the public administration in order to enter in the "social market" of care services.

The presence of more professionals in the organizational structure, also, pushes in the direction of adopting a wide array of systems of evaluation and assessment of organization's performance and impact. 


\section{Figure 2.1. Converging trends (pressures) toward the adoption of Social Impact assessment measurement systems in Nonprofit Organizations / Social Enterprises}

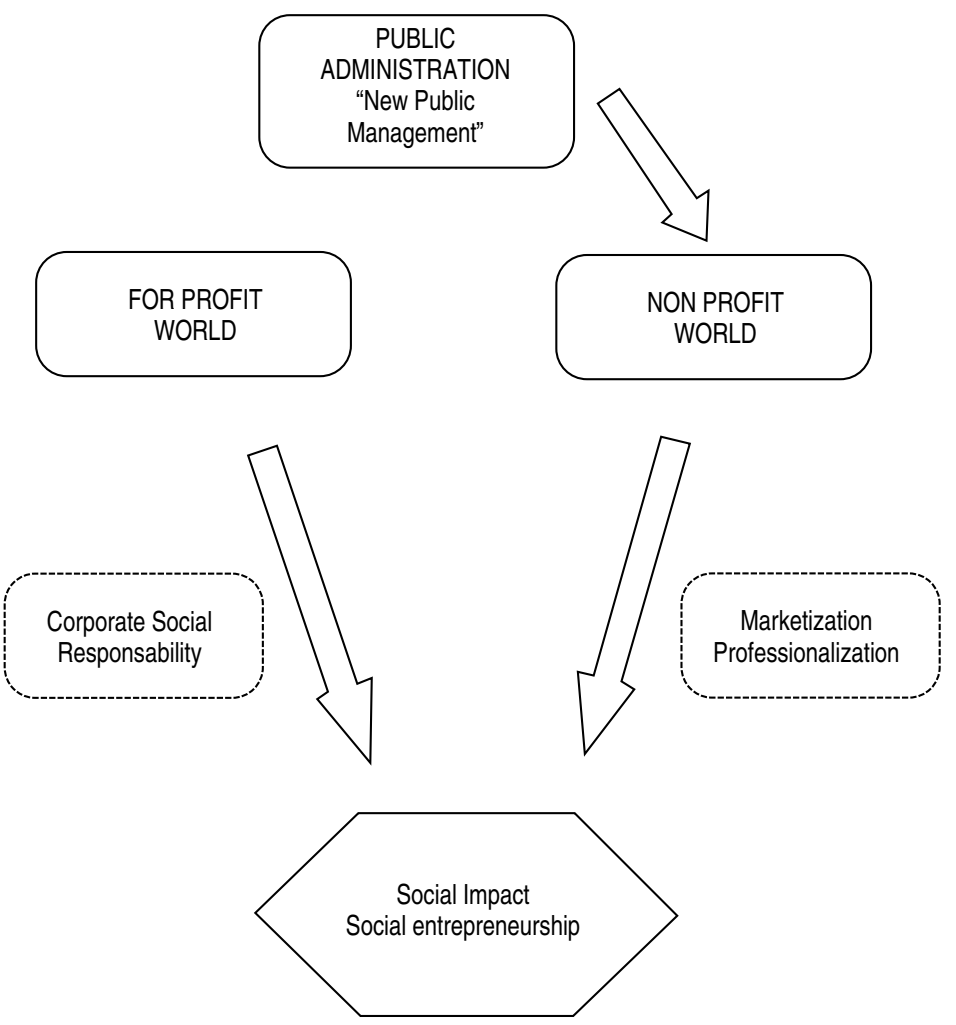

\subsection{A framework for measuring social performance}

In a very insightful article published in 2010 in the Working Paper Series of the Harvard Business School, Ebrahim A. and Rangan V.K propose a "framework for measuring social performance" using as target the NGOs - nongovernmental organization operating in "third world" or "under developed" countries. 
The authors recognize that many definitions of impact refer to a logic chain of results in which organizational inputs and activities lead to a series of outputs, outcomes, and ultimately to a set of societal impacts (see Table 2.1).

Given the above mentioned framework they state that:

"Our normative argument is that it is not feasible, or even desirable, for all organizations to develop metrics at all levels on the logic chain. The more important challenge is one of alignment. building systems and structures for measurement that support the achievement of organizational mission, especially the goals that an organization can reasonably control or influence. We contend that organizational efforts extending beyond this scope are a misallocation of scarce resources." (p. 4)

They develop a contingency approach for measuring social performance based on the assumption that - because of the varied work, aims, and capacities of social sector organizations - some organizations should be measuring long-term impacts, while others should stick to measuring shorterterm results. This approach offers a logic for determining which kinds of measures are appropriate, as driven by the mission and goals of the organization.

They are aware of the fact that in times of economic crisis the pressures to demonstrate impact are likely to increase across all the actors involved (private funders, nonprofit leaders, government), as public and private resources diminish and as competition for existing resources increases.

There is no doubts that the growing emphasis on impact and accountability has increased the pressure on social sector organizations to pay attention to performance measurement. Therefore there are three main challenges in front of the nonprofit managers and leaders:

"- What can my organization reasonably measure on the logic chain — inputs, activities, outputs, outcomes, or impacts?

- What does my organization need to measure for accountability to funders?

- How can my organization use measurement to help it better achieve its mission?" (p. 17)

The authors affirm that two deeper analytical problems are implied by these questions: (a) the problem of causality, meaning how well understood is the relationship between cause and effect of an intervention; and they refer to an organization's causal logic as its theory of change. (b) the problem of control over results, meaning the ways in which managers exercise control over their interventions and results.

In order to illustrate their argument Ebrahim and Rangan, choose the example of the role of the social sector in the field of poverty alleviation. They indicate three broad types of activities: 
"- Emergency relief - activities that address urgent survival needs, such as food and temporary shelter, as well as disaster, crisis and conflict mitigation.

- Service delivery - activities that address basic needs, such as education, healthcare, longerterm shelter, community development, employment and income generation.

- Policy and rights advocacy - activities that address structural issues related to rights, public policy and regulation, and societal norms." (p. 19)

After a very deep and careful analysis of several examples of intervention in this field, they summarize their observations in the following propositions that relate performance measurement to the type of social sector activity:

"1. Performance in emergency and relief work can be measured in terms of inputs, activities, and outputs;

2. Performance in service delivery work can be measured in terms of activities and outputs;

3. Performance in service delivery work, when of large scale and scope, can be measured in terms of outcomes and sometimes impacts;

4. Performance in advocacy and rights-based work can be measured in terms of outputs and "influence," an intermediary outcome." (p. 22)

Based on this empirical analysis they propose a contingency framework for assessing the different types of results that can be measured (see Figure 2.2).

The vertical axis of the matrix refers to the causal logic underlying an activity. As mentioned before a theory of change shows the pathway through which a set of interventions is expected to lead to a certain goal. The key point here is the level of complexity is involved in the relationship between cause and effect, and the degree of awareness. There are at least two situations: focused and complex. In the first one the relationship between cause and effect is linear and clearly understood. The second one refers to cause-effect relationships that are weakly understood, and where there are multiple causal factors.

The horizontal axis of the matrix - operational strategy - concerns what an organization actually does in implementing its mission. Also from this point of view there are two main possibilities: focused and complex. In the first case the nonprofit concentrates on a highly specific task or intervention; each organizational actor fills a specific and critical niche. In the second one, the organizations expand its boundaries to absorb other key functions or niches, that play a key role in achieving their mission.

Following this line of reasoning Ebrahim and Rangan distinguish among four broad types of results: niche, integrated, institutional, and ecosystem (see Figure 2.2).

Regarding the organizations in the niche quadrant, it is feasible to rely on simple measures of the organization's inputs, activities, and outputs. It would not be useful to try to measure long-term 
impacts, since that is not what niche efforts can reasonably control, nor necessarily what the organization aims to achieve. The organizations in the integrated results quadrant usually are able to measure their outputs and also outcomes.

As far as the organizations in the institutional quadrant are concerned, it may be feasible to measure their outputs and their "influence" in shaping key policies (as intermediate outcomes), but not necessarily their impacts. The reason lays in the fact that impacts are more likely to be achieved by networks or coalitions of actors working in concert, than by single organizations acting alone.

Finally, organizations in the ecosystem quadrant are focused on issues that are difficult to be clearly defined, and involve multiple interventions and roles. The fulfillment of their mission requires synergistic results that affect entire systems. Measuring these impacts requires long time frames. In this case impacts are more likely to be achieved through partnerships and collaborations, because usually it is not possible to attribute impacts exclusively to any one actor.

The authors conclude with the following statement:

"The discussions around impact measurement, both within the U.S. and internationally have been somewhat polarized - between those who demand clear and quantifiable measures of impact and those who contend that social sector work is so unique and context-specific that it cannot be readily measured. Our contingency framework attempts to move beyond such reductionism by differentiating among types of results." (p. 30)

\section{Table 2.1. Logic Model}

\begin{tabular}{|c|c|c|c|c|}
\hline Inputs & Activities & Outputs & Outcomes & Impacts \\
\hline What goes in & What happens & What results - immediate & $\begin{array}{l}\text { What results - } \\
\text { medium-long term }\end{array}$ & $\begin{array}{l}\text { What results - effects on } \\
\text { root causes; sustained sig- } \\
\text { nificant change }\end{array}$ \\
\hline $\begin{array}{l}\text { - funds } \\
\text { - equipment } \\
\text { and supplies } \\
\text { - knowledge and } \\
\text { technical expertise }\end{array}$ & $\begin{array}{l}\text { - basic needs delivered, } \\
\text { such as food and shelter } \\
\text { - services delivered, such } \\
\text { as training programs } \\
\text { - capacity building } \\
\text { - construction of infrastructure } \\
\text { - policy dialogues and } \\
\text { workshops }\end{array}$ & $\begin{array}{l}\text { - people fed, treated or } \\
\text { housed } \\
\text { - people trained or educated } \\
\text { - roads built } \\
\text { - goods transported to } \\
\text { market and sold } \\
\text { - policy papers written } \\
\text { - coalitions and networks } \\
\text { built }\end{array}$ & $\begin{array}{l}\text { • improved living } \\
\text { conditions, health, } \\
\text { etc. } \\
\text { • increased } \\
\text { incomes } \\
\text { - enhanced politi- } \\
\text { cal voice }\end{array}$ & $\begin{array}{l}\text { - sustained drop in poverty } \\
\text { - changes in public policy } \\
\text { and regulation } \\
\text { - increased rights and politi- } \\
\text { cal power } \\
\text { - fundamental changes in } \\
\text { social norms and attitudes } \\
\text { (on rights, freedoms, gover- } \\
\text { nance, and markets) }\end{array}$ \\
\hline
\end{tabular}

SOURCE: Ebrahim A., Rangan V.K. 2010, p. 49. 


\section{Figure 2.2. A Contingency Framework for Measuring Results}

\begin{tabular}{|c|c|c|}
\hline & Focused & Complex \\
\hline $\begin{array}{l}\text { Theory of Change } \\
\text { Focused }\end{array}$ & $\begin{array}{l}\text { Niche Results } \\
\text { - Basic and emergency services, soup kitchens, } \\
\text { crisis drop-in centers and Hotlines } \\
\text { - Measure inputs, activities, outputs }\end{array}$ & $\begin{array}{l}\text { Integrated Results } \\
\text { - Service delivery (in health, education, } \\
\text { employment), immunization campaigns, } \\
\text { com-plex emergency services } \\
\text { - Measure aggregate outputs, outcomes, } \\
\text { and sometimes impacts }\end{array}$ \\
\hline $\begin{array}{l}\text { Theory of Change } \\
\text { Complex }\end{array}$ & $\begin{array}{l}\text { Institutional Results } \\
\text { - Change in societal norms and policies (on } \\
\text { rights and freedoms, good governance, } \\
\text { efficient markets) } \\
\text { - Measure outputs and "influence" (intermedi- } \\
\text { ate outcomes) }\end{array}$ & $\begin{array}{l}\text { Ecosystem Results } \\
\text { - Economic development, comprehensive } \\
\text { rural develop-ment and natural resource } \\
\text { management, collaborative de-velopment } \\
\text { - Measure outcomes and impacts }\end{array}$ \\
\hline
\end{tabular}

SOURCE: Ebrahim A., Rangan V.K. 2010, p. 52.

Assuming this multidimensional approach - and for the purpose of this article - we will adopt the following definition of Social Impact2:

A lasting change (positive or negative) in the environment of the organization influenced directly or indirectly, intended or unintended - by the organizational activities.

The decision making process concerning the social impact assessment involve several organizational dimensions that can be summarized by the following questions: whether, why, what, who, when and how.

The first point is concerning the degree of awareness that the different internal stakeholders of the organizations have about the necessity/opportunity to measure the social impact. Given the fact that a certain kind of evaluation of organization's social performance is always present, the organizations can differ on the level of consciousness that this process is active and on the way it is implemented: implicit or explicit, directly or indirectly (through the opinions of external stakeholders).

2.- As Ebrahim A., Rangan V.K suggest, we would prefer the term societal impact instead of social impact in order to define the overall contribution that a nonprofit organization or a social enterprise produce for the society as a whole. Given the fact that an organization produces several different types of impact: economic, political, social and cultural. But since in the international scientific literature the common used term is the latter, in this paper they will be used as synonymous. 
The second issue regards the reasons, the motives, on the base of which the governing body of the organization take the decision to undertake a program of social impact assessment/evaluation. These could be leaded mainly by economic rationales (funders and donors concerns); or by political reasons (to increase the organization's reputation and legitimization, or image and visibility in the local community); or by social rationale (to evaluate the quality of the relationships, partnerships, networks, the organization is member of; and the level of trust by other organizations); or by ethical motives (linked to the ideological, religious, moral orientation of the organizations; level of consistency with the mission's values).

The third aspect concerns the level and the object of analysis. The social impact assessment could concern, at least, three level of analysis: micro (a project), meso (the organization itself) and macro (a service or a program). The evaluation could be directed towards two main objects: processes or products. Finally it could concern two main type of results: tangible (outputs) or intangible (outcomes).

The fourth dimension is taking into consideration the subject/actor of the assessment process. Indeed the social impact can be evaluate or internally (by some sub-unit of the organization) or externally (by a third party: a private or public body, for instance the social audit procedure).

The fifth point is relating to the time of realization of the evaluation process, that can be: before the start of a project, program or service (prevision analysis), during its implementation (monitoring the ongoing activities), or after its conclusion (short-medium-long term effects).

Finally, the sixth and last aspect, regards a more practical level of the decision making process namely the choice of the best evaluation tools to be adopted. "Best" in this case refers to the "adequacy" and "appropriateness" of the tool in relation to the object and the level of analysis, on one side, and the type of organization's activities, on the other side. The "accuracy" and "correctness" of the tool can be measured in terms of the quantity and quality of social performance indicators it requires in order to operate properly. 


\section{Table 2.2. The sub-dimensions of the Social Impact} assessment process

\begin{tabular}{|c|c|}
\hline Questions & Elements \\
\hline Whether & $\begin{array}{l}\text { - conscious } \\
\text { - in-conscious } \\
\text { - direct } \\
\text { - indirect }\end{array}$ \\
\hline Why & $\begin{array}{l}\text { Rationales/Motives: } \\
\text { - Economic } \\
\text { - Political } \\
\text { - Social } \\
\text { - Ethical }\end{array}$ \\
\hline What & $\begin{array}{l}\text { Level of analysis: } \\
\text { - project } \\
\text { - organization } \\
\text { - activity/service } \\
\text { Object of analysis: } \\
\text { - process } \\
\text { - product } \\
\text { Type of objects: } \\
\text { - tangible } \\
\text { - intangible }\end{array}$ \\
\hline Who & $\begin{array}{l}\text { - Internal } \\
\text { - External }\end{array}$ \\
\hline When & $\begin{array}{l}\text { - Ex ante } \\
\text { - In itinere } \\
\text { - Ex post }\end{array}$ \\
\hline How & $\begin{array}{l}\text { - Tools } \\
\text { - Indicators }\end{array}$ \\
\hline
\end{tabular}

In the following pages we will present briefly our social impact assessment model called SAVE, namely: social added value evaluation. 


\section{3.- The Social Added Value Evaluation approach}

In order to cope with the issues illustrated in the previous paragraph, a research group at the Department of Sociology - Bologna University began a Research Project ${ }^{3}$ aimed to develop a theoretical framework based on which to elaborate a methodological tool for the assessment of the social impact that nonprofit organizations and social enterprises produce in the community (environment) in which they operate.

At this stage of our scientific program we propose to differentiate the specific contribution (outcome and impact) of the third sector organizations (non-profit organizations and social enterprises) at each of the dimensions of social life: micro, meso and macro.

At the micro level the distinctive function of NPO/SE is to produce: a sense of responsibility, both among their members and towards the public (for people/ citizens); at the meso level it is their ability to produce a certain number of relational goods 4 (or collective goods, or meritorious goods) for organisations and the local territorial systems; finally at the macro level it is their capacity to generate a solid amount of social capital$/ 5$ for the complex social systems or the vast community.

Following this theoretical approach it is clear that the distinctiveness of NPO / SE type of organizations is to be evaluated not so much looking at what they produced but rather mainly looking at how they produce, and above all with and for whom they produce. Sociology.

3.- The group belongs to the Ce.S.I.S. (Research Center of Social Innovation) directed by Prof. Pierpaolo Donati, at the Department of

4.- The definition of relational good is of the Italian sociologist Pierpaolo Donati, and it has been developed in a scientific research program of more than thirty years. It refer to a good or service that holds the following characteristics: a) it is a good where the production, distribution and consuming require the involvement of both the producer and the user; $b$ ) it is a good that can be enjoyed only by and through the social relation; c) the quality of the good is embedded in the social relation. The relational good differs both from the public and the private goods. See: Donati P. (a cura di) 1996, pp. 37-39.

5.- On the concept of social capital there is nowadays a wide bibliography. For a review of the principal approaches and an original version of the concept see Donati P. 2007; Donati P. e Tronca L. 2008; Colozzi I. 2005. These are some of the main definitions around which the scientific debate did develop:

Pierre Bourdieu (1980, 1986): "[social capital is] the sum of resources, actual or virtual, that accrue to an individual or a group by virtue of possessing a durable network of more or less institutionalized relationships of mutual acquaintance and recognition."

James Coleman (1988, 1990): "Social capital is defined by its function. It is not a single entity, but a variety of different entities having two characteristics in common: They all consist of some aspect of social structure, and they facilitate certain actions of individuals who are within the structure. Like other forms of capital, social capital is productive, making possible the achievement of certain ends that would not be attainable in its absence."

Robert Putnam (1993, 1995, 1996): "social capital ... refers to features of social organization, such as trust, norms, and networks, that can improve the efficiency of society by facilitating coordinated actions."

CIRIEC-España, Revista de Economía Pública, Social y Cooperativa

№ $83 / 2015$, pp. 9-42

ISSN: 0213-8093 
We assume that the degree of "sense of responsibility", the amount of "relational goods" and the level of "social capital" that a NPO/SE creates/produces/generates all together represent what we call the social added value that this organization produce for the whole society, at a given time.

We can define the social value as follows:

- The increase in the quantity and quality of meaningful relationships (social relations) due to the organization activities;

- The decrease of consumption of meaningful relationships (social relations) linked to the organization's way of operate.

In this research path we elaborated the so called S.A.V.E. (Social Added Value Evaluation) system of assessment based on four internal organisational dimensions:

- Resources (both human and economic-financial) management (A);

- Political-strategic planning (Governance - G);

- Activities and processes (I); and

- Culture and values (L).

\section{Figure 3.1. The four internal process of a Nonprofit organization / Social Enterprise}

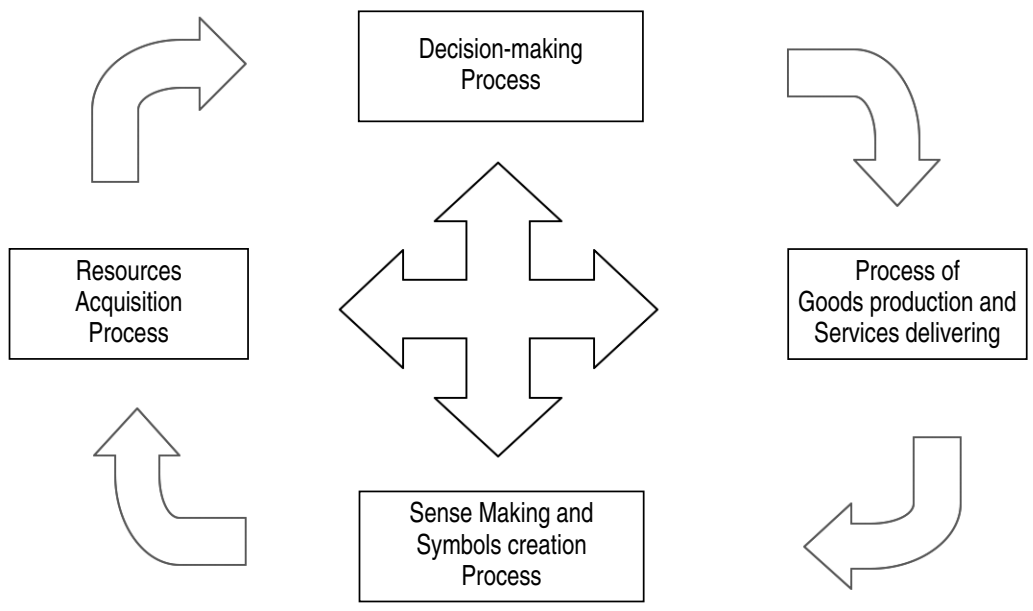




\section{Figure 3.2. The internal organisational dimensions of} SAVE ("Social added value" evaluation)
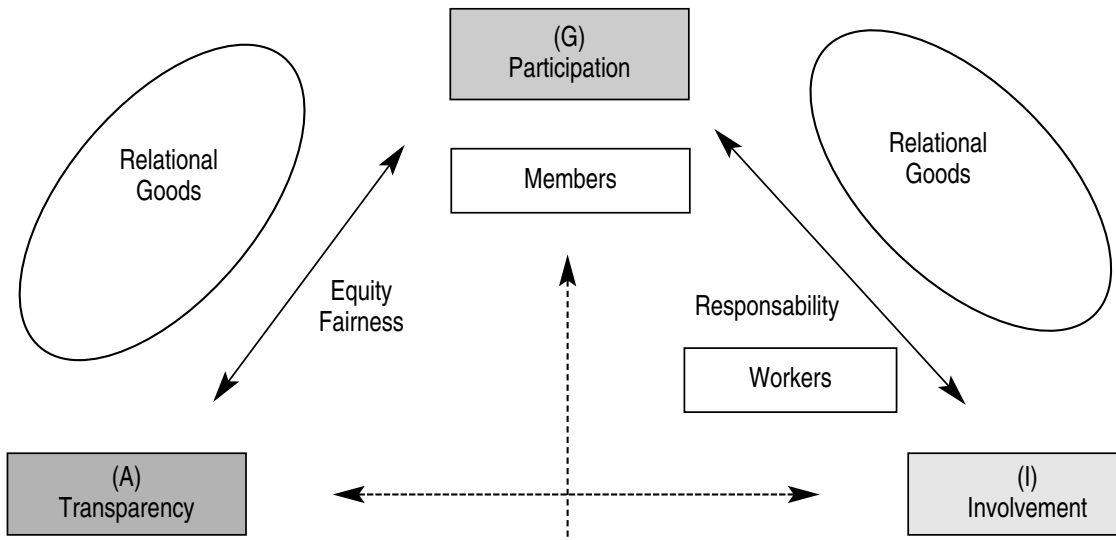

(I)

Involvement
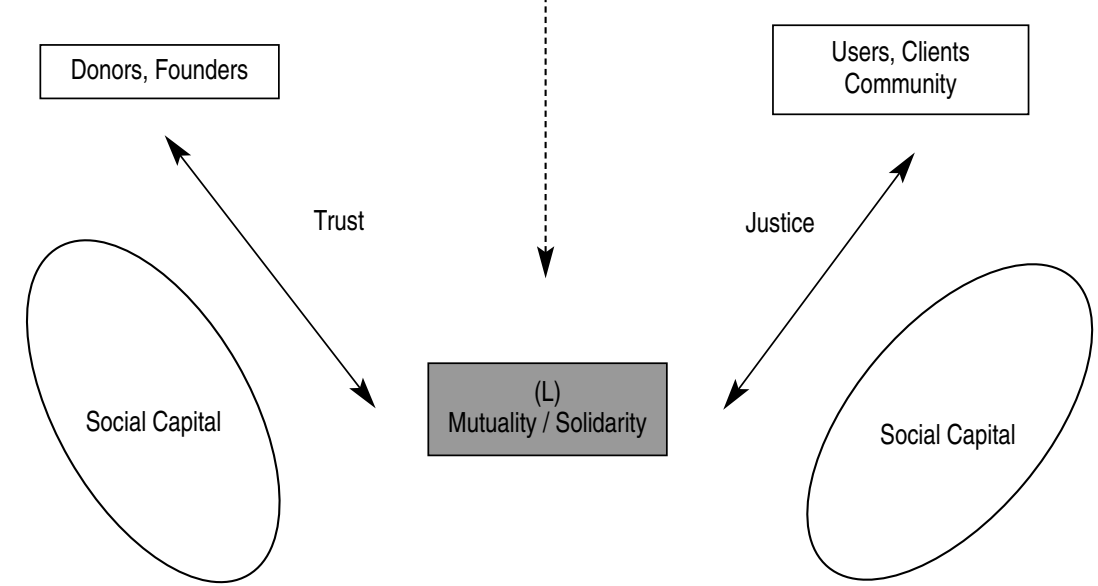

Organizations of volunteers $=$ gift/gratuitousness;

Associations = participation/democracy;

Social Coops/Social Enterprises = work/profession/self-governance;

Foundations = management/belonging;

The relation $A-G=$ follows the principle of fairness

The relation $\mathrm{G}-\mathrm{I}$ = follows the principle of responsibility

The relation $I-L=$ follows the principle of justice

The relation $L-A=$ follows the principle of trust 
The first dimension regards the way in which NPO/SE manage the process of creating resources (revenues) and the relationships which they establish with donors and financial backers, on one side, and the way in which they are able to attract specific typology of human resources (such as volunteers). The central questions are: do the NPO/SE operate in a transparent and correct way from the point of view of economic resource management? Does their capacity to recruit volunteers and highly motivated persons change (increase, decrease or remain stable) during a certain period of time (i.e. three years)?

The second dimension analyses the internal chain of the decision-making process and evaluates the degree to which the members of the organisation participate in it. The fundamental question is, to what extent does the system of governance promote the participation of members and different kind of internal stakeholders, such as: workers, volunteers, etc.?

The third dimension constitutes the heart of the SAVE system and takes into consideration the internal process of providing the goods or services produced. It illuminates the way in which the various NPO/SE (external) stakeholders (users, clients, consumers, families, other actors in the community, etc.) are involved in the organisation's activities.

The fourth dimension concerns the process of commitment to values or to the creation of values. It shows the impact that the NPO/SE' activities have on the local community or society in general. It aims to measure the level of social capital and of social cohesion created by the organisation (their capacity to create trust, networking, partnerships, etc.).

For each dimension were identified key core concepts around which to build a set of indicators for measuring the VAS. Given below are some examples.

With regard to the first dimension (economic, financial, human resource acquisition) the semantic nuclei are as follows:

a) ability (and development over time) of the NPO/SE to "activate volunteer human resources" in the local community where the NPO/SE operate;

b) ability (and development over time) of the NPO/SE to "enable economic resources as donations" in the local (or ideal) community where the NPO/SE operate;

c) ability (and development over time) of the NPO/SE to "communicate in a transparent manner" its work to its stakeholders (method of social reporting, and procedures for the dissemination/sharing of this Report: social accountability). 
With regard to the second dimension (political - strategic, decision-making) the semantic nuclei are as follows:

d) ability of the NPO/SE to "promote, encourage, foster democratic participation" of all internal stakeholders in decision-making process;

e) the ability of the NPO/SE to "favour, encourage and promote the replacement/turn over" of its leadership (how to manage the succession process of organizational leadership);

With regard to the third dimension (managerial and operational, for carrying out the production process, and service delivery), which concerns the production of relational goods, the semantic nuclei are as follows:

f) ability of the NPO/SE to "promote, encourage, foster the involvement" of the internal stakeholders (members, paid workers, volunteers, etc.) at different stages of the process of service delivery (design, implementation, evaluation);

g) ability of the NPO/SE to "promote, encourage, foster the involvement of" external stakeholders (users, beneficiaries, families, communities, customers / suppliers , etc.) at different stages of the process of service delivery (design, execution, evaluation);

With regard to the fourth dimension (production, deployment and activation of meaning, culture and values), which is the ability to generate social capital (trust), the semantic nuclei are as follows:

h) degree of reputation/trust of the NPO/SE in the community, geographical area where the organization operate;

i) ability of the NPO/SE to "networking" or to work together with other local entities: public, private, non- profit organizations;

j) capacity of the NPO/SE to establish "partnership" with other public, private and nonprofit actors.

A useful tool in order to give an "easy to read" representation of the explanatory capacity of the SAVE model is to elaborate a graphic version of it. We adopted as reference model the so-called "Civil Society Diamond" elaborated by a group of international scholars within the project "The Civil Society Index" created by CIVICUS - World Alliance for Citizens Participation 6 .

To this end it was started a work of indexing of the above mentioned indicators that allows to reach a high degree of formalization of their final version and therefore of their measurement and representation. 
Figure 3.3 shows a possible application of the "diamond" by entering the data of an Italian social enterprise working the welfare sector. The square / diamond formed by the red lines indicate the average values (score 3 ) on the 1-5 scale and represents the ideal- type (median) of NPO/SE, in respect of which to compare the actual status of the organization (or group of organizations, or Region, or sector of services) under scrutiny. Which is represented here by the rhombus formed by blue lines.

The distances (gaps) for each dimension between the mean values (standard) and the actual values, show clearly and directly the strengths and weaknesses of the organization examined. The areas ie with respect to which the NPO/SE ranks above average and those in respect of which instead it shows values lower than expected, and thus constitute organizational areas on which to focus policies aimed to improve the quality of its performance.

In the case exposed here, the social enterprise shows good performance for the production of social added value in three areas: "Resources" $(+1)$, "Governance" $(+0.2)$, and "Impacts " $(+0.4)$, while it reveals a lower value than expected in relation to the process/dimension of service delivery: "output/outcome" (-1.3).

This means that the organization in question has been able to put in place arrangements for management and reporting of both human and financial-economic resources in a "fair and transparent" way, consistent with its organizational mission. Secondly, the TSO has been able to implement ways and means of participation of stakeholders that ensure a good influence and control over decision-making, and, thirdly, has been able to build lasting relationships (trustworthy) with its local community, towards which it has generated social capital.

While it appeared incomplete and deficient in the capacity to engage users and beneficiaries of services in the various phases of the service delivering process (production of "relational goods").

Figure 3.4 illustrates the possibility to "explode" each of the four basic dimensions in two or more sub-dimensions, so allowing a graphic representation of " 8 or 12 or 16" or more sub-indicators (two, three, four or even more for each main dimension). Increasing the explanatory power of the SAVE model.

In the following paragraphs we will present the result of the application of the SAVE model in three case studies of Italian social enterprises. 


\section{Figure 3.3. The SAVE Diamond}

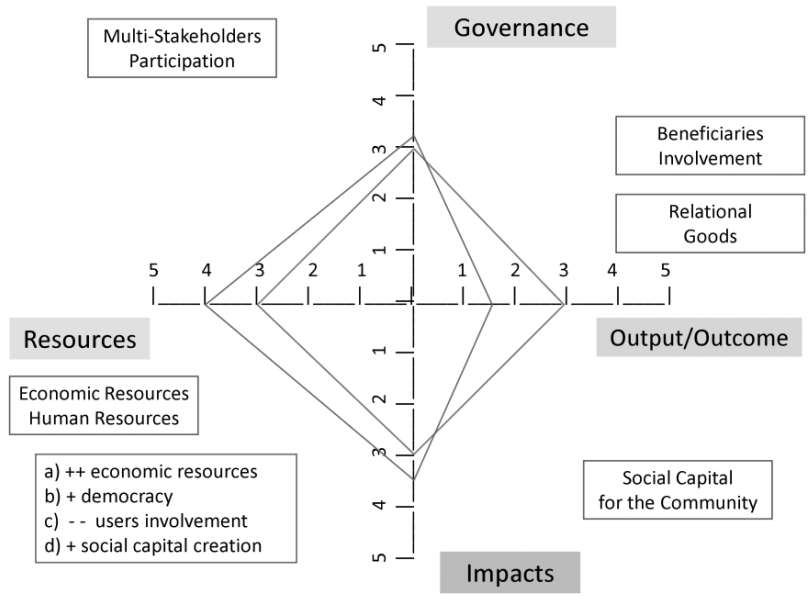

\section{Figure 3.4 - The SAVE Diamond - sub-dimensions}

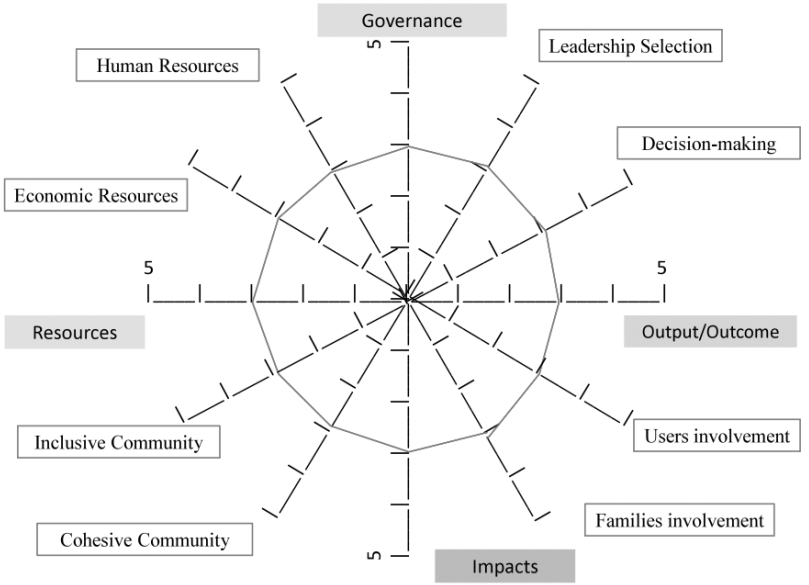




\section{4.- The social cooperative movement in Italy}

\subsection{A short history of Italian Social Cooperatives}

In Italy the reality of social cooperation has developed in a relatively short period of time, but with an intensity that have indelibly marked its current welfare system.

Social cooperatives are private enterprises - therefore they take the legal form of a company (Book $V$ of the Civil Code) - which are born with the aim of: "pursue the general interest of the community to promote human and social integration of citizens" (Law no. 381/1991 - Article 1); through: a) the delivering of social, health and educational services; b) the performance of different activities - agricultural, industrial, commercial or services - aimed at providing employment opportunities for disadvantaged people.

There two type of Social Cooperatives: Type A: social co-operatives for the delivering of social, health and education services; and Type B: social cooperatives that operate in a variety of productive activities but whose purpose is to promote the employment of disadvantaged people.

The type A Social Cooperatives dealing in: home care to the elderly, the sick, the psychiatric patients; run community homes and day care centers for children and the handicapped; are concerned with the child care services; and provide educational and recreational services for children at risk.

The type B Social Cooperatives can operate in any business activities - agricultural, industrial, commercial, trade, services, with the specificity to allocate a portion of the jobs created in this way to disadvantaged people (at least 30\%), otherwise excluded from the labor market.

Besides the two basic types, there are cooperative with mixed object $(A+B)$, they deliver activities that take place both on the supply of health services and education, and activities aimed at providing employment for disadvantaged people; and Social Consortia, that is, corporate groups set up as cooperative societies, which have their social basis formed by social cooperatives (not less than seventy per cent).

To lay the groundwork for the emergence and development of what can be defined as the form of social entrepreneurship for excellence (Borzaga, Zandonai, 2009) was the cultural and political climate has spread to the sunset of the Sixties: a season marked by momentous changes and decisive claims by a significant proportion of people (students and workers in particular) who loudly demanded the inalienability of their rights as men and citizens, regardless of their social, economic or mental health. 
The incessant demand for more personalized and diversified services according to the needs of the individual at the time, revealed an evident lack of the State with respect to its caring, health, social security and employment responsibilities. Despite the enactment of several important legislative measures, such as the Law no. 482 of 1968 on compulsory employment or the Law n. 833 of 1978 on the National Health Service, there were many people who were excluded from the system of protection and, therefore, forced to live in a situation of social exclusion. This was especially the mentally ill, the disabled, the prisoners and, later, drug addicts, who were not specifically granted nor social spaces nor the possibility of a job.

It is at this time that groups of volunteers - mainly from the Catholic world - begin to "ferment" in many Italian cities, with the explicit aim to respond - in a gratuitous way - to the needs of disadvantaged citizens in the name of civic responsibility and a duty of solidarity towards the others. These associational movements may be considered in all respects the forerunners of today's social cooperatives, as it is their specific values configuration, based on democracy and the sharing (Marzocchi, 2012), that aroused autonomous organizations with a specific legal form.

In the following years (especially since 1980) social cooperatives grew at a phenomenal rate and began to sign agreements and contracts with the local public administration, the latter attracted by the possibility, on the one hand, to stabilize new services (also introducing quality elements) and, on the other hand, to save on the financial expenditure, in a period in which the prosperity of the economic boom was gradually extinguished.

During the "90s the public administration made a widespread use of "invitations to tender" to "the lowest bidder", resulting in the isomorphism of social cooperation (Colozzi and Bassi, 2003), which produced a substantial hybridization with respect to public bureaucracies or businesses firms, fueled by assessment and evaluation systems that do not meet the actual specificity of the sector (think of the standards ISO 9000).

Despite the obvious risks of distortion and loss of identity still widely felt (Colozzi, 2011), this organizational form has been able to expand - both in number of organizations and membership - and become independent, following its peculiar civil and moral inclinations. On a formal level this recognition came in basically two key steps:

1) through the enactment of Law no. 381 of 1991 (Regulation of Social Cooperatives), which establishes the purposes and types; 2) through the introduction of "local area care Plans" and the "system of accreditation", as provided by Law no. 3282000 (National System of Welfare Services).

This last measure, in particular, has established the role of cooperatives in the design phase of social policies at the local level, proving to be a viable tool of "voice" for the citizens main social problems as well as a resource of the community to be promoted. 
In this favorable situation, the Italian social co-operation has continued to grow, both in terms of number of organizational units (+ $98.5 \%$ compared to 2001 - Source: Istat) and in terms of the range of services delivered, and its presence does not seem destined for anything to decrease.

\subsection{The research design}

The exploratory research consisted of the realization of three case studies, identified inside the social cooperation movement of Emilia-Romagna Region, on the basis of a principle of heterogeneity, in order to test hypotheses about the social added value (SAV) produced by these particular type of social enterprise.

The social enterprises analyzed were detected by means of an interview with the regional manager of social cooperatives Legacoop Emilia-Romagna, one of the main cooperatives umbrella Association operating at national level. Through this meeting, we came to identify the most appropriate units to participate in the research project, considering both their availability and their interest toward the issue under study.

In order to gather the maximum level of information about the SAV produced by co-operatives, both quantitative and qualitative methodological tools have been used.

Concerning the first type of tool, we developed a structured questionnaire containing organizational data (number of members/workers/volunteers/users; structure of revenue and their growth over time; membership in consortia, representative bodies, networks, etc.). Through this instrument we have been able to get a full picture of the "state of health" of the social cooperatives examined, and to have an idea of the changes taking place.

As qualitative tools, we have opted for the collection and analysis of "information material" and "official documents" of the organizations (articles of incorporation, services charter, social balance, etc..); in order to reconstruct the history of the cooperative, to identify the main areas of services and activities, and to recognize its guiding values. We realized also a semi-structured interview with the President or the administrative manager of the organization. The research has been conducted in the period: September 2013 - March 2014.

Given the objective to discover the different aspects of SAV, such as the ability to produce relational goods and generate social capital, the interview was divided into four sections of information:

1. Ways of acquiring and managing financial and human resources; to check the consistency / adequacy of these kind of inputs towards its stated objectives. Secondly the presence / absence of adequate reporting tools (transparency in accountability); 
2. Structure of the decision-making system (governance); with particular reference to participatory practices of organization's members;

3. nternal process of service delivery (outputs and outcomes); in order to assess the degree of involvement of the various stakeholders;

4. Effects (impacts) of the activities on the local community; in terms of production, activation and implementation of social capital.

The data were processed and analyzed through the elaboration of evaluation indices, containing a set of indicators to which it was assigned a score from 0 to 5 (minimum / maximum) ${ }^{7}$. The average of the scores of each indicator allowed us to have a synthetic "measure" (on base of 5) of the level / degree of achievement of the SAV for the four dimensions of analysis.

To facilitate readability and communicability of these results, a graphic representation called "the diamond" has been realized. This tool showed - in a clear and direct way - the distance (gap) between the mean values (score 3 ) and the actual values of the organization.

The sum of the four dimensions' scores (maximum of 20), led to the identification of the distinctiveness of social enterprises under study. This operation has proved to be particularly suited to bring out the social added value of social cooperatives, in respect of the current evaluation tools adopted by non-profit organizations. Indeed, often the SAV is neglected or even dwarfed by assessment procedures which are inadequate because primarily focused on quantitative (tangible) rather than qualitative (intangible) aspects of the organization processes and operations.

\section{5.- Three case studies of Social Cooperatives}

\subsection{The Social Cooperatives Analyzed}

The three Social cooperatives object of testing the SAV model of analysis, operate in the EmiliaRomagna Region, but with specific characteristics with regard to: the territorial scope of intervention, the activities' sector, the objectives, the organization's size, the number of users in charge, and so on. 
The first one is the social cooperative "Tragitti", founded in 1991 by a previous volunteering and associative experience, it has as main objective the psychosocial assistance and rehabilitation, in order to foster the social and human promotion of disadvantaged people. It is a mixed type of social cooperative, ie delivers both social welfare services as well as services for the job insertion of people in charge. It has an organizational dimension much smaller than the other (64 workers, including 56 members and 1 volunteer) and operates at a local level, in the area of Forli, Cesena and Imola municipalities. It carries out activities aimed to assist, rehabilitate and support people with mental health problems (65 users in 2012). To this end it runs two socio-rehabilitative Residences, a psychiatric nursing Home, a community Housing and, finally, a "psychiatric Apartment". Among the guiding principles there are: equality, impartiality, continuity, participation, right to choose, efficiency and effectiveness.

The second one is the social cooperative "Nazareno", which was born in the same period (1990) and work at the regional level to assist persons with disabilities (physical or mental), referring to the same inspirational values. It manages "prolonged treatment nursing Homes" in the territory of the municipalities of Carpi, Sorbara and Bologna for people with severe mental disorders; day care Centers and "education to work Centers" aimed to increase the employment opportunities of the users. It also runs "expressive workshops" in favor of its users (144 in total in 2012), such as theater, music, dance activities; and it is engaged in the production of an annual International Festival that gathers artists with disabilities from around the world, with the aim to value the person and his talents. It has a mediumlarge organizational dimension (179 members, 122 employees), with a particularly large number of volunteers (total 99), that periodically carry out activities in support of the residential care facilities.

The third one is the social cooperative "Ambra" which is the "youngest" of the three (year of establishment: 1995), but it is distinct in size from several points of view. It is the only one to operate at national level; it has a very large organizational structure (554 members and 754 employees); it has a high number of users (total 2,028 in 2012); and, finally, it has an higher level of income than the other case studies.

It actually works in many areas of services (childcare, mental health and education, the elderly) and this can explain its different conformation. Compared to their activities, the cooperative is responsible for designing and managing: Nurseries, Kindergartens and child care Centers; it delivers education support and integration in Schools for students with disabilities, as well as pedagogical advice. In the area of mental health, it designs and implements interventions to prevent discomfort, deviance and violence in the local area; and it manages educational, residential and semi-residential services. Concerning the elderly, it manages facilities and integrated services (nursing Homes, sheltered Housing, RSA, groups Apartment, day care Centers), designing specific interventions (services and cores for senile dementia, outpatient rehabilitation) and, finally, it delivers integrated home care services.

As it is clear from this brief description, the chosen case studies are quite dissimilar from each other and represent a good sample of the social cooperative movement in the Region, which is highly heterogeneous. Therefore they seems to be particularly suitable for making comparisons and to test effectively the SAV assessment model. 


\subsection{Results and comments}

The purpose of the empirical investigation was to assess the distinctiveness, or the Social Added Value, of three social cooperatives operating in the Emilia-Romagna Region, in order to highlight their particular organizational structure and their impact in the social context.

Considering the above mentioned four dimensions of analysis, the social cooperatives under study showed the following results (See Annex 1 for an explanation of the indicators used for each index).

First dimension (Index of consistency or resource adequacy): there was a significant heterogeneity between the various cooperatives analyzed, especially in terms of the number of members, territorial intervention, source of revenue, accounting procedures, etc.. These differences are primarily due to the dimensional characteristics of the same organizations, which vary from one case to another and have a profound effect on the results of the SAV measurement for this section of analysis.

In particular, only a cooperative (Coop. n. 1) obtained a positive value, as it has proven to be more able to activate donatives financial resources and gratuitousness resources. The other two organizations, however, have reported lower scores, claiming to be able to rely on a smaller number of donations and volunteers, and to adopt informal tools of accountability rather than set up ad hoc instruments.

\section{Figure 5.1. Resources Adequacy Index}

\begin{tabular}{|l|ccc|}
\hline & $\begin{array}{c}\text { Coop. 1 } \\
\text { (Ambra) }\end{array}$ & $\begin{array}{c}\text { Coop. 2 } \\
\text { (Nazareno) }\end{array}$ & $\begin{array}{c}\text { Coop. 3 } \\
\text { (Tragitti) }\end{array}$ \\
\hline Capacity to activate community resources (Donations) & 3 & 1 & 1 \\
Capacity to activate solidaristic resources (Volunteers) & 3 & 5 & 1 \\
Capacity of social reporting (accountability) (Social Report) & 5 & 1 & 1 \\
\hline Total & 11 & 7 & 3 \\
\hline Index of Resources Appropriateness $[(\mathrm{a}+\mathrm{b}+\mathrm{c}) / \mathrm{n}]$ & $\mathbf{3 , 7}$ & $\mathbf{2 , 3}$ & $\mathbf{1}$ \\
\hline
\end{tabular}

Concerning the second dimension (Internal Democracy Index) the scores were quite high for all of the organizations analyzed; demonstrating in particular the presence in each associative reality of strong synergies and sharing among members regarding the decisions to be taken (decision making process). 


\section{Figure 5.2. Index of internal democracy}

\begin{tabular}{|l|ccc|}
\hline & Coop. 1 & Coop. 2 & Coop. 3 \\
\hline $\begin{array}{l}\text { Capacity of members involvement } \\
\text { Implementation of other tools of participation in addition to } \\
\text { those established in the by-law }\end{array}$ & 5 & 5 & 5 \\
\hline Total & 3 & 5 & 3 \\
\hline Index of Internal Democracy & 8 & 10 & 8 \\
\hline
\end{tabular}

Third dimension (Relational Operational Capacity Index): also in this case the results were positive, since each cooperative examined showed to adopt concrete inclusive and participatory strategies in favor of its direct and indirect beneficiaries; focused to the promotion of an effective co-design of services. Thus, the cooperative principles of participation, involvement and inclusion appear generally respected, contributing to the achievement of a good level of SAV.

\section{Figure 5.3. Index of relational capacity}

\begin{tabular}{|l|ccc|}
\hline & Coop. 1 & Coop. 2 & Coop. 3 \\
\hline Capacity of services planning & 5 & 5 & 3 \\
Capacity of services monitoring & 5 & 5 & 5 \\
Capacity to communicate the results & 5 & 3 & 3 \\
Capacity of users involvement & 5 & 5 & 5 \\
Capacity of users' family involvement & 5 & 3 & 3 \\
Capacity of other stakeholders & 5 & 3 & 3 \\
Capacity to adapt to criticalities & 5 & 5 & 5 \\
Level of conviviality & 5 & 5 & 5 \\
\hline Total & 40 & 34 & 32 \\
\hline Index of Relational Operational Capacity & $\mathbf{5}$ & $\mathbf{4 , 2 5}$ & $\mathbf{4}$ \\
\hline
\end{tabular}

Fourth dimension (Social Impact Index): in this section various aspects of the ability to generate social capital have been analyzed; such as: the ability to develop networks with other organizations and the surrounding territory; to generate other non-profit organizations; to promote initiatives addressed to the citizens; to influence the actions of other organizations (non-profit or public) and, finally, to be involved in the planning processes of local policies. The results were quite satisfactory, especially compared to the number of collaborations activated with other non-profit and the ability to sensitize the community on several social issues. 


\section{Figure 5.4. Index of Social Impact}

\begin{tabular}{|l|ccc|}
\hline & Coop. 1 & Coop. 2 & Coop. 3 \\
\hline Capacity to develop networks & 5 & 5 & 5 \\
Generativa capacity & 1 & 5 & 3 \\
Promotional capacity & 5 & 5 & 5 \\
Innovative capacity & 3 & 3 & 1 \\
Degree of involvement in the social policy planning at the local level & 1 & 3 & 1 \\
\hline Total & 15 & 21 & 15 \\
\hline Index of Social Impact & $\mathbf{3}$ & $\mathbf{4 , 2}$ & $\mathbf{3}$ \\
\hline
\end{tabular}

The following "diamond" graphs illustrates - in a clear and direct way - the results obtained by individual cooperatives for each dimension of analysis, showing the distance (gap) between the benchmark (mean values $=$ score 3 ), represented by the red lines, and the actual values, indicated by the blue lines.

\section{Figure 5.5. The SAVE diamond Plot}

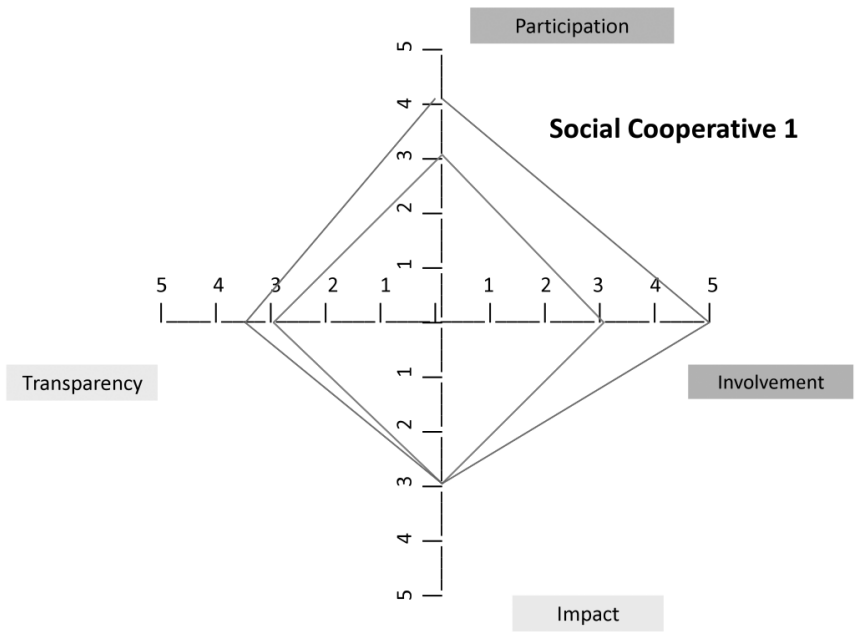



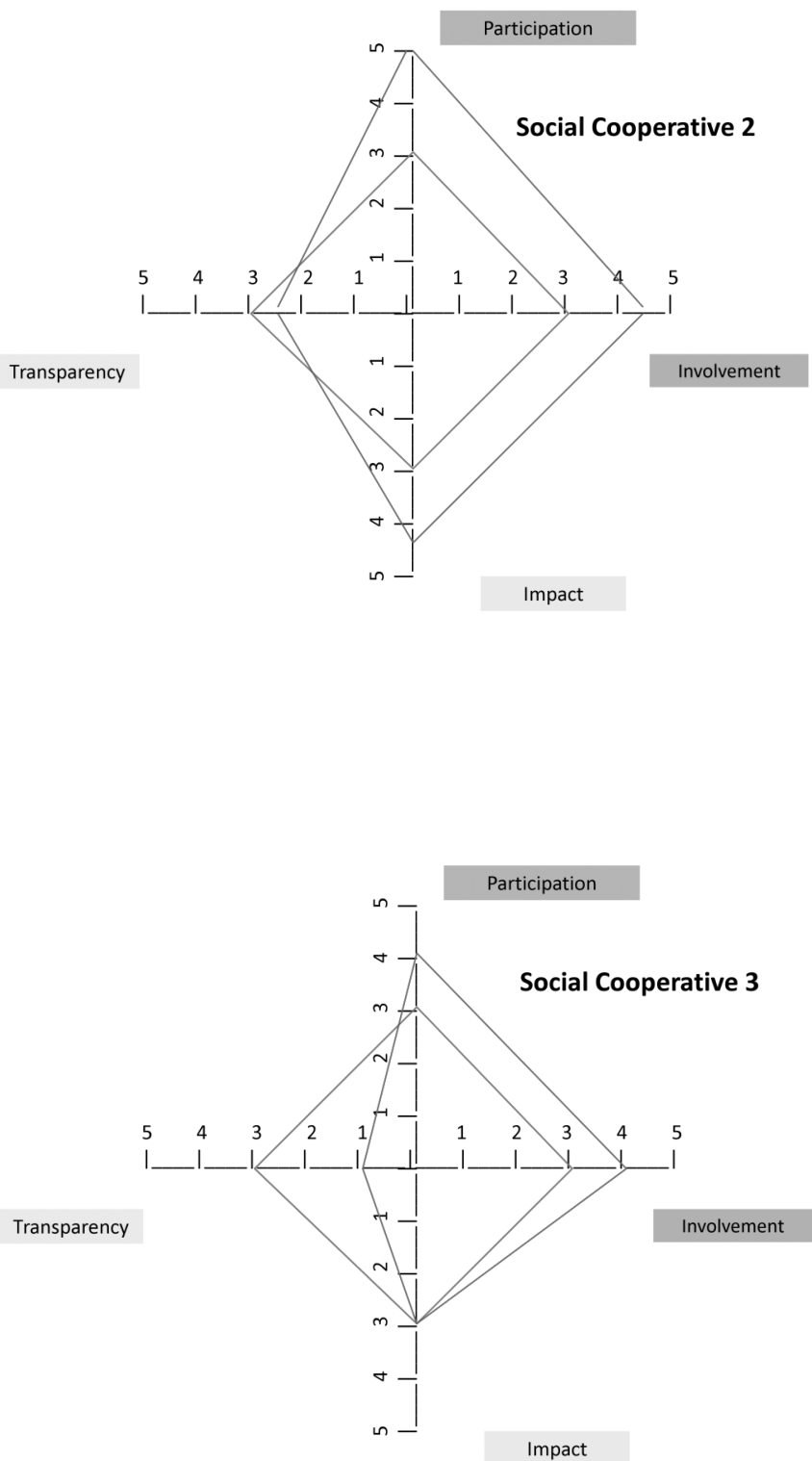

CIRIEC-España, Revista de Economía Pública, Social y Cooperativa № 83/2015, 9-42

ISSN: 0213-8093 
The following table shows for each social cooperative the total score obtained, which represent the level of social added value (SAV) on a twenty point scale.

\section{Figure 5.6. The Social Added Value Index}

\begin{tabular}{|l|ccc|}
\hline & Coop. 1 & Coop. 2 & Coop. 3 \\
\hline Index of Resources Adequacy & 3,7 & 2,3 & 1 \\
Index of Internal Democracy & 4 & 5 & 4 \\
Index of Relational Operational Capacity & 5 & 4,25 & 4 \\
Index of Social Impact & 3 & 4,2 & 3 \\
\hline Social Added Value (SAV) & $\mathbf{1 5 , 7}$ & $\mathbf{1 5 , 7 5}$ & $\mathbf{1 2}$ \\
\hline
\end{tabular}

Given the fact that in accordance with our evaluation model the highest score of the SAV produced by a nonprofit organization is twenty, looking at the data of Figure 5.6 it can be said that two out of three cooperatives have achieved a "satisfactory result".

The social cooperatives we analyzed demonstrate the presence of "identity peculiarities" that in our opinion should not be neglected in the system of "contracting out" services to third parties and in their assessment models by the Italian Public Administration, as well as by the social cooperatives themselves (in their self evaluation processes).

\section{6.- Concluding remarks}

The main focus of the chapter has been the issue of evaluation of nonprofit organizations / social enterprises performance, and especially of Italian social cooperatives operating in the field of care services (local welfare system) - in terms of intangible or relational goods they generate.

In Italy the gradual and sometimes ambiguous legal recognition of social enterprises has gone hand in hand with the formulation of mechanisms of organizational performance assessment which proved to be inadequate. Mainly because they have been designed around the scrupulous respect of quantitative standards (formal evaluation), and they have been intended as a means to obtain cost savings and to guarantee the maximum level of control by the public administration agencies on the service delivering process. 
This need emerges as a result of the significant amount of public resources directed to the field of social policies on the part of the public sector, which has proved to be increasingly careful and meticulous in the allocation of certain tasks to third parties - mainly to nonprofit organizations - in a economic situation characterized by a huge decrease in the spending capacity of public administration.

Social cooperatives have been particularly affected (damaged) by these new methods of administration of welfare policies, based more on quantitative than on qualitative aspects of services delivering. Their being systematically subjected to inappropriate evaluation procedures, linked to a contractual relationship with the local government, has obscured their capacity to produce a social impact (social added value) in their territorial area as "social enterprises", namely a multi-membership based organization with a plurality of stakeholders deeply embedded in the local community.

This contribution starts by the acknowledgment of these criticalities, due mainly to the lack of recognition of nonprofit organizations distinctiveness and the consequent risk of distortion (organizational isomorphism), by the current accreditation systems. It aimed to offer an alternative system of evaluation and monitoring of the activities of social enterprises, that is more able to value their specificities and to promote their peculiarities as autonomous actors of civil society.

We hope that such an attempt will be properly adopted and diffused amongst the public administration "evaluators" and also by those third sector organizations that intend to value their capacity to provide relational services and to generate social capital, namely to promote and reinforce their particular way of "being" and "act" in the society. 


\section{Annex 1. Sub-dimensions of Index construction}

\begin{tabular}{|c|c|}
\hline $\begin{array}{l}\text { Index of Resources } \\
\text { Appropriateness }\end{array}$ & \\
\hline $\begin{array}{l}\text { Capacity to activate community } \\
\text { resources (Donations) }\end{array}$ & $\begin{array}{l}\text { Analysis of the composition and the trend of economic and financial resources, with parti- } \\
\text { cular reference to non-public funds ("risk" of organizational isomorphism): fund raising, " } 5 \\
\text { for thousand" fiscal campaign, sponsorships, etc. }\end{array}$ \\
\hline $\begin{array}{l}\text { Capacity to activate solidaristic } \\
\text { resources (Volunteers) }\end{array}$ & $\begin{array}{l}\text { Evaluation of the presence and role of volunteers in the social structure and their } \\
\text { evolution over time (increase/decrease). }\end{array}$ \\
\hline $\begin{array}{l}\text { Capacity of social reporting } \\
\text { (accountability) } \\
\text { (Social Report) }\end{array}$ & $\begin{array}{l}\text { Use of communication tools in order to increase transparency and corporate } \\
\text { responsibility, such as: "Services Charter", "Social Report", "Activity Report", workshops, } \\
\text { conferences, seminars, brochures. }\end{array}$ \\
\hline \multicolumn{2}{|l|}{ Index of Internal Democracy } \\
\hline $\begin{array}{l}\text { Capacity of members } \\
\text { involvement }\end{array}$ & $\begin{array}{l}\text { Analysis of the methods / tools used by the cooperative to promote the participation of } \\
\text { members: number of General Assemblies, cadence, and types of participants (open or } \\
\text { closed). Particular attention is given to the involvement of its members in relation to three } \\
\text { important moments of organizational life: selection/appointment of the President; } \\
\text { choice/appointment of board members; key strategic and policy choices. }\end{array}$ \\
\hline $\begin{array}{l}\text { Implementation of other tools of } \\
\text { participation in addition to those } \\
\text { established in the by-law }\end{array}$ & $\begin{array}{l}\text { Analysis of the presence, composition and function of other organs of consultation, such } \\
\text { as: Steering Committees, Consultation Committees, Ethical Committees; Scientific } \\
\text { Boards; regular Teams meeting, etc. }\end{array}$ \\
\hline \multicolumn{2}{|l|}{$\begin{array}{l}\text { Index of Relational } \\
\text { Operational Capacity }\end{array}$} \\
\hline Capacity of services planning & $\begin{array}{l}\text { Analysis of the ways of programming and design services in order to involve the } \\
\text { users/clients, and to favor the user/worker relationship. }\end{array}$ \\
\hline Capacity of services monitoring & $\begin{array}{l}\text { Analysis of the monitoring tools (evaluation methodologies) of the services' trend and } \\
\text { their "positioning" in time (ex-ante, ex-post). }\end{array}$ \\
\hline $\begin{array}{l}\text { Capacity to communicate the } \\
\text { results }\end{array}$ & $\begin{array}{l}\text { Analysis of the presence of communication channels (formal / informal) aimed at infor- } \\
\text { ming stakeholders of the results achieved and the ways of diffusion (internal meetings, } \\
\text { website, etc.). }\end{array}$ \\
\hline Capacity of users involvement & $\begin{array}{l}\text { Analysis of the degree of users' participation with respect to three different organizational } \\
\text { phases: services' planning (design), implementation (delivering) and evaluation (low, } \\
\text { medium and high level). }\end{array}$ \\
\hline $\begin{array}{l}\text { Capacity of users' family } \\
\text { involvement }\end{array}$ & $\begin{array}{l}\text { Analysis of the degree of users family members' involvement with respect to the areas of: } \\
\text { services' planning (design), implementation (delivering) and evaluation (low, medium and } \\
\text { high level). }\end{array}$ \\
\hline $\begin{array}{l}\text { Capacity of other stakeholders } \\
\text { involvement }\end{array}$ & $\begin{array}{l}\text { Evaluation of the ability of influence (low, medium, high) of other stakeholders (donors, } \\
\text { backers, workers, community leaders) towards the services delivering process. }\end{array}$ \\
\hline Capacity to adapt to the critical & $\begin{array}{l}\text { Analysis of the changes introduced in the service delivering process as a result of "wrong" } \\
\text { practices (the ability to take account of failures: learning by doing). }\end{array}$ \\
\hline
\end{tabular}

CIRIEC-España, Revista de Economía Pública, Social y Cooperativa

№ $83 / 2015$, pp. 9-42

ISSN: 0213-8093 


\begin{tabular}{|l|l|}
\hline Level of conviviality & $\begin{array}{l}\text { Detection of the number and quality of socialization initiatives (parties, dinners, trips, etc.) } \\
\text { addressed to various stakeholders (workers, volunteers, service users, donors, families, } \\
\text { etc.). }\end{array}$ \\
\hline \multicolumn{1}{|c|}{ Index of Social Impact } & \\
\hline Capacity to develop networks & $\begin{array}{l}\text { Presence and type of relationships with other organizations and the local community } \\
\text { (co-partnership; light collaboration, etc.); intensity/importance of the relationship and } \\
\text { degree of trustworthiness. }\end{array}$ \\
\hline Generative capacity & $\begin{array}{l}\text { In the last three years, did the organization under scrutiny create other associations or } \\
\text { groups? (yes/no; and numbers of). }\end{array}$ \\
\hline Promotional capacity & $\begin{array}{l}\text { In the last three years, did the organization under scrutiny promote and realize activities } \\
\text { towards the population in the local community? (eg awareness campaigns on topics rela- } \\
\text { ted to the mission of the cooperative) (yes/no; and numbers of). }\end{array}$ \\
\hline Innovative capacity & $\begin{array}{l}\text { In the last three years, did the organization under scrutiny develop and realize new servi- } \\
\text { ces provisions or new ways of services delivering, which have been able to influence the } \\
\text { actions of other non-profit organizations or public administration bodies, or which have } \\
\text { been adopted by them? (yes/no; and numbers of). }\end{array}$ \\
\hline $\begin{array}{l}\text { Degree of involvement in the } \\
\text { social policy planning at the } \\
\text { local level }\end{array}$ & $\begin{array}{l}\text { Assessment of the level of cooperative's involvement (participation) in the planning pro- } \\
\text { cesses of local services (eg in the annual Social Services Area Plan enacted by the muni- } \\
\text { cipality). }\end{array}$ \\
\hline
\end{tabular}

\section{References}

ANTADZE, N. \& WESTLEY, F.R. (2012): "Impact Metrics for Social Innovation: Barriers of Bridge sto Radical change?", Journal of Social Entrepreneurship, 3 (2), 133-150.

BASSI, A. (2013): "How to measure the intangibles, Towards a system of indicators (S.A.V.E.) for the measurement of the performance of social enterprises". In: Hans-Werner Franz, Jürgen Howaldt, Josef Hochgerner (eds.), Challenge Social Innovation. Potentials for Business, Social Entrepreneurship, Welfare and Civil Society, Berlin, Springer, 326-350.

BASSI, A. (2014): "The Social Added Value of Third Sector Organizations". In: L. Boccacin (Ed.), Third Sector, Partnerships and Social Outcome. The Cases of Italy and Ireland, Vita e Pensiero, Milano, 76-108.

BILLIS, D. (Ed.) (2010): Hybrid Organizations and the Third Sector, Palgrave MacMillan, New York.

BERTOTTI, M., LEAHY, G., SHERIDAN, K., TOBI, P. \& RENTON, A. (2011): "Measuring the impact of social enterprises", British Journal of Healthcare Management, 17 (4), 152-156. 
BRENNAN, D., CASS, B., HIMMELWEIT, S. \& SZEBEHELY, M. (2012): "The marketisation of care: rationales and consequences in Nordic and liberal care regimes", Journal of European Social Policy, 22, 377-391.

BORZAGA, C., ZANDONAI, F. (a cura di) (2009): L'impresa sociale in Italia. Economia e istituzioni dei beni comuni, Rapporto Iris Network, Donzelli Editore, Roma.

COLOZZI, I. (2011): "Delle virtù e dei premi, ovvero come riconoscere le Organizzazioni di Terzo Settore di qualità, come premiarle e disseminare processi emulativi delle buone pratiche". In: S. Zamagni (Ed.), II libro bianco sul Terzo settore, II Mulino, Bologna, 245-281.

COLOZZI, I. \& BASSI, A. (2003): Da Terzo settore a Imprese Sociali. Introduzione all'analisi delle organizzazioni non profit, Carrocci, Roma.

DEFOURNY, J., HULGARD, L. \& PESTOFF, V. (2014): Social Enterprise and the Third Sector. Changing European Landscapes in a Comparative Perspective, Routledge, London and New York.

DI DOMENICO, M.L., HAUGH, H. \& TRACEY, P. (2010): "Social Bricolage: Theorizing Social Value Creation in Social Enterprises", Entrepreneurship Theory and Practice, 34 (4), 681-703.

DONATI, P. \& COLOZZI, I. (a cura di) (2004): Il privato sociale che emerge: realtà e dilemmi, II Mulino, Bologna.

EBRAHIM, A. \& RANGAN V.K. (2010): The Limits of Nonprofit Impact: A Contingency Framework for Measuring Social Performance, Social Enterprise Initiative, Harvard Business School - Working Paper 10-099, http://hbswk.hbs.edu/item/6439.html

HEMERIJCK, A. (2012): "Retrenchment, redistribution, Capacitating Welfare Provision, and institutional Coherence after the Eurozone's austerity reflex", Sociologica, 1, II Mulino Bologna.

ISTAT (2013): Nono censimento dell'industria e dei servizi e Censimento delle istituzioni non profit, primi risultati, Roma.

LECY, J.D., SCHMITZ, H.P. \& SWEDLUNG, H. (2012): "Non-Governmental and Not-for-Profit Organizational Effectiveness: A Modern Synthesis", Voluntas, 23 (2), 434-457.

LYON, F. \& ARVIDSON, M. (2011): Social impact measurement as an entrepreneurial process, Third Sector Research Centre, TSRC Briefing Paper 66.

MARZOCCHI, F. (2012): Storia tascabile della cooperazione sociale in Italia. Con un occhio rivolto al futuro, I Quaderni dell'Economia Civile, n. 2.

MEAGHER, G. \& SZEBEHELY, M. (2013): Marketization in Nordic eldercare: a research report on legislation, oversight, extent and consequences, US-AB, Stockholm.

PIERSON, P. (2011): The Welfare State over the very long run, Zentrum für Sozialpolitik, Universität Bremen, ZeS-Working Paper n. 02/2011.

STANDING, H. (2004): Understanding the "demand side" in service delivery. Definitions, frameworks and tools from the health sector, DFID Health Systems Resource Center, London, UK. 